\title{
External Costs on The Island of Vis: Comparison of two Traffic Modes
}

\section{Luka Vukića, Lidija Runko Luttenberger ${ }^{b}$, Katarina Balića, Merica Sliškovića}

External cost of road traffic, identified as the highest among traffic modes, is an important indicator of the European Union's transport policy to shift traffic off the road to a more environmentally acceptable mode. Ferry traffic generates benefits to each port of call in localities having invested in port infrastructure, and there is an interest of the local community to have their own ferry line, especially on islands. Two alternative ferry lines have been created combining maritime and road traffic on the specific route from the town of Vis to the town of Komiža and compared from the external costs standpoint. The first alternative ferry line comprises one port of call in the town of Vis, combining it with a road modality to and from the town of Komiža. In the second alternative, the road traffic has been excluded and two ferry ports of call have been introduced, one towards the town of Vis and the other by extending the ferry voyage to the town of Komiža. The results show the model of one port of call with the integration of more road traffic on the specific route as a better solution. Despite the use of ultra-low sulphur diesel fuel on ferries, the absence of congestion in road traffic on the island of Vis and generally slow implementation of modern emission standards in maritime traffic, road traffic seems to provide a better solution as an environmentally more acceptable mode on this route.

\footnotetext{
a. University of Split, Faculty of Maritime Studies, Split, Croatia

e-mail: luka.vukic@pfst.hr

b. Faculty of Maritime Studies, University of Rijeka, Croatia

e-mail: lidija.luttenberger@uniri.hr

doi: 10.7225/toms.v08.n02.008

This work is licensed under (cc) BY
}

\author{
KEY WORDS \\ $\sim$ External costs \\ $\sim$ Comparison \\ $\sim$ Traffic modes \\ $\sim$ Island \& Vis
}

\section{INTRODUCTION}

Current EU transport policy pays special attention to the socio-ecological aspect of transport and sustainability (EC, 2009), while external costs are an important tool for measuring the impact of traffic on environment and health (Van Lier, 2016). Road traffic is known as the worst traffic polluter with external costs mainly due to traffic congestion, accidents, and emissions (Maibach et al., 2008). Maritime traffic is more often relieved of congestion and accidents and involves only emission pollutants. For this reason, it is considered to be an environmentally acceptable means of transport. On the islands, where maritime traffic links are particularly important for providing benefits in each port of call (Luttenberger, 2012), there is a great deal of local community interest in establishing their own ferry line. However, the inclusion of external costs in practice as a market-competitive criterion is not so easy and paradoxical results are not uncommon. Each traffic route should be examined and evaluated from the external costs point of view, in order to determine which mode of transport is the most environmentally acceptable (Vukić \& Poletan Jugović, 2016). The research shows such an example from the island of Vis in Croatia.

\section{AIM}

On the island of Vis, there are two main towns: Vis and Komiža. They are connected by road and naturally, by sea. Both 
towns have the ports suitable for ferry traffic. But only the town of Vis is connected to the mainland by a ferry line. Vehicles with a final destination in the town of Komiža disembark in the town of Vis and continue the journey by road carrying the stigma of high external costs. The survey examines whether or not the external costs would be lower in case of further travel from the town of Vis to the town of Komiža by ferry.

\section{MATERIAL AND METHODS}

The ferry "Petar Hektorović" travels from Split to the town of Vis. The distance of voyage is $35 \mathrm{M}$ and it lasts for 2 hours and 20 minutes. It is powered by two KRUPP-MaK diesel engines of 1800 kW each (ShipSpotting, 2018). Combustion is $210 \mathrm{~g} / \mathrm{kWh}$ of Euro diesel. The distance between the two towns on the island is 11 $M$ by sea. The frequency of ferry lines was three times a day in 62 days in the high tourist season and two times a day in 303 days in the low season in 2017.

The road distance between two towns on the island is 10 $\mathrm{km}$. The combustion of road vehicles was calculated using the models of car (capacity $<2.5 \mathrm{t}, 70 \mathrm{~kW}$ ) and truck (capacity $<7.5 \mathrm{t}$, $200 \mathrm{~kW}$, speed $50 \mathrm{~km} / \mathrm{h}$ ). The technical data has been downloaded from the technical sheets (Table 1).

Table 1.

Characteristics of the engines of vehicles in the research.

\begin{tabular}{lllll} 
Vehicle & Engine; Power & Fuel; Specific gravity & Combustion & Load \\
\hline Car (passenger) & Otto; $70 \mathrm{~kW}$ & Gasoline; 0.75 & $7 \mathrm{l} / 100 \mathrm{~km}^{*}$ & $75 \%$ \\
Truck (HDV) & Diesel; $200 \mathrm{~kW}$ & Eurodiesel; 0.85 & $157.5 \mathrm{~g} / \mathrm{kWh}$ & $75 \%$ \\
Ferry & Diesel; $3600 \mathrm{~kW}$ & Eurodiesel; 0.85 & $210 \mathrm{~g} / \mathrm{kWh}$ & $100 \%$
\end{tabular}

*calculated consumption value 52.5 g/km (Source: Shipspotting, 2017; Ančić, 2016; ICCT, 2016; own data-modified)

There were 52,912 vehicles transported by this ferry line in 2017 (CLSA, 2018). According to the last census data (CBS, 2011) and the number of tourist visitors in 2017 (Split and Dalmatia County..., 2018), it is estimated that $41 \%$ of vehicles had the final destination in the town of Komiža (Table 2).

The technical sheets have been used for the emission factor values (CO2, PM2.5/PM10, SOx, NOx) and unit prices of pollutants for each type of fuel including MDO (Marine distillate oil) that is no longer in use on ferries here (Table 3 and 4).
The unit prices of pollutants (Korzhenevych et al., 2014) have been used in order to make the range of valorisation results more understandable, not the current prices. The field research has shown that there has never been any congestion, and accidents are very rare on the road between the two towns. They have therefore been excluded from the calculation of external costs.

By multiplying the amount of fuel consumed, the emission factors and the unit prices of pollutants the external costs for all types of examined vehicles have been calculated and then compared for two alternative routes.

Table 2.

Traffic of transported vehicles on the examined ferry line in 2017, the number of tourist visitors in 2017 and the last official census in the examined destinations.

(Source: CLSA, 2018; CBS, 2011; Split and Dalmatia County..., 2018; Jadrolinija 2018)

\begin{tabular}{lllll} 
Line/Destination & $\begin{array}{l}\text { Annual number of } \\
\text { voyages in 2017 }\end{array}$ & $\begin{array}{l}\text { Annual number of } \\
\text { transported vehicles in } \\
2017\end{array}$ & $\begin{array}{l}\text { Annual tourist visitors in } \\
2017 \text { (share \%) }\end{array}$ & $\begin{array}{l}\text { Last official census in } \\
2011(\text { share \%) }\end{array}$ \\
\hline Split - Vis & 792 & 52,912 & $28,394(61 \%)$ & $1,934(56 \%)$ \\
& & Vis & $17,935(39 \%)$ & $1,526(44 \%$
\end{tabular}


Table 3.

Emission factors (EF) in road and ferry traffic $(\mathrm{g} / \mathrm{kg})$.

\begin{tabular}{llllll} 
Vehicle & Fuel & PM10/PM2.5 & NOx & SOx & CO2 \\
\hline Passenger car* & Gasoline - Euro 5 & $0.041 / 0.041$ & 3.512 & 0.001 & 3,130 \\
HDV** & Euro diesel - Euro 5 & $0.203 / 0.192$ & 12.245 & 0.015 & 3,170 \\
Ferry & Eurodiesel (0.001 \% S) & $0.203 / 0.192$ & $36.66^{* * *}$ & 0.015 & 3,170 \\
& MDO**** (0.1 \% S) & $1.6 / 1.5$ & 46.58 & 1.158 & 3,170
\end{tabular}

*0.18g/km NOx (ICCT, 2016)

** Heavy duty vehicle, EF 2g/kWh NOx (ICCT, 2016), Power engine 200 kW, Load $75 \%$

***calculated value, Tier II, 2100 o/min, EF 7.7 g/kWh NOx, SFOC $210 \mathrm{~g} / \mathrm{kWh}$ (Ančić, 2016), Power engine 3600 kW, Load $100 \%$

****Marine diesel oil (Source: Statistics Norway, 2017 - modified)

Table 4.

Air pollution costs of main pollutants in traffic $(€ / t)$.

\begin{tabular}{llccc} 
Vehicle & CO2 & SOx & NOx & $\begin{array}{c}\text { PM2.5/PM10* } \\
\text { rural }\end{array}$ \\
\hline Car (passenger) & & & & $31,649 / 5,064$ \\
Truck (HDV) & 90 & 12,317 & 15,149 & $31,649 / 5,064$ \\
Ferry & 90 & 12,317 & 15,149 & $18,500 / 2,960$
\end{tabular}

*unit price PM10=16 \% PM2.5 (TU Delft, 2012), (Source: Korzhenevych et al., 2014 - modified)

\section{RESULTS}

The results of the calculation of external costs for the two alternative routes are shown in Table 5-8. Given the unknown types of road vehicles driving to Komiža, the calculation assumes that all vehicles were passenger cars in one case and that all vehicles were trucks in the other one. Calculation of external costs of a ferry using MDO shows the size of the benefit of fuel change.

Table 5 .

Calculation of external costs on the route Vis-Komiža by ferry using Eurodiesel.

Vis - Komiža ferry*

Consumption

Eurodiesel

Emissions and

valorization

SOx

NOx

PM10

PM2.5

$\mathrm{CO} 2$

Total

*distance $11 \mathrm{M}$, speed $15 \mathrm{kn}$, time $0.73 \mathrm{~h}$, no. voyages 792
Calculation

engine power $\times$ SFOC $\times$ time $=$ fuel $(\mathrm{kg})$ $3,600 \times 0.21 \times 0.73=551.88 \mathrm{~kg}$

emission factor $\times$ consumption $x$ unit price $=$ external cost $(€)$ $0.015 \times 551.88 \times 6.7=0.06 €$ $36.66 \times 551.88 \times 1.85=37.43$

$0.203 \times 551.88 \times 2.96=0.33$

$0.192 \times 551.88 \times 18.5=1.96$

$3,170 \times 551.88 \times 0.09=157.45$

external cost $x$ no. voyages $x 2$

$197.23 \times 792 \times 2=312,412.32 €$ 
Table 6.

Calculation of external costs on the route Vis-Komiža by ferry using MDO

Vis - Komiža ferry*

Consumption

MDO

Emissions and

valorization

SOx

NOx

PM10

PM2.5

$\mathrm{CO} 2$

Total

*distance $11 \mathrm{M}$, speed $15 \mathrm{kn}$, time $0.73 \mathrm{~h}$, no. voyages $792 \times 2$
Calculation

engine power $\times$ SFOC $x$ time $=$ fuel $(\mathrm{kg})$ $3,600 \times 0.21 \times 0.73=551.88 \mathrm{~kg}$

emission factor $\mathrm{x}$ consumption $\mathrm{x}$ unit price $=$ external cost $(€)$

$1.158 \times 551.88 \times 6.7=4.28$

$46.58 \times 551.88 \times 1.85=47.56$

$1.6 \times 551.88 \times 2.96=2.61$

$1.5 \times 551.88 \times 18.5=15.32$

$3,170 \times 551.88 \times 0.09=157.45$

external cost $\times$ no. voyages $\times 2$

$227.22 \times 792 \times 2=359,916.48 €$

Table 7.

Calculation of external costs on the route Vis-Komiža for a car using gasoline.

Vis - Komiža road*

Consumption, car (passenger)

Gasoline

Emissions and

valorization

SOx

NOx

PM10

PM2.5

$\mathrm{CO} 2$

Total

*distance $10 \mathrm{~km}$, consumption $52.5 \mathrm{~g} / \mathrm{km}$

distance $10 \mathrm{~km}$, consun
Calculation

consumption $\mathrm{x}$ distance $\times 2=$ fuel $(\mathrm{kg})$

$52.5 \times 10 \times 2=1.05$

emission factor $\mathrm{x}$ consumption $\mathrm{x}$ unit price $\mathrm{x}$ no. vehicles $=$ external cost $(€)$

$0.001 \times 1.05 \times 12.32 \times 21,694=0.28$

$3.512 \times 1.05 \times 15.15 \times 21,694=1,211.98$

$0.041 \times 1.05 \times 5.06 \times 21,694=4.73$

$0.041 \times 1.05 \times 31.65 \times 21,694=29.56$

$3,130 \times 1.05 \times 0.09 \times 21,694=6,416.76$

$7,663.31 €$

Table 8.

Calculation of external costs on the route Vis-Komiža for a truck using Euro diesel.

Vis - Komiža road*

Consumption, truck (HDV)

Eurodiesel

Emissions and

valorization

SOx

NOx

PM10

PM2.5

$\mathrm{CO} 2$

Total
Calculation

SFOC $x$ engine power $x$ time $\times 2=$ fuel $(\mathrm{kg})$ $157.5 \times 200 \times 0.2 \times 2=12.6$

emission factor $\mathrm{x}$ consumption $\mathrm{x}$ unit price $\mathrm{x}$ vehicles no. $=$ external cost $(€)$

$0.015 \times 12.6 \times 12.32 \times 21,694=50.51$

$12.245 \times 12.6 \times 15.15 \times 21,694=50,708.6$

$0.203 \times 12.6 \times 5.06 \times 21,694=280.77$

$0.192 \times 12.6 \times 31.65 \times 21,694=1,661.06$

$3,170 \times 12.6 \times 0.09 \times 21,694=77,985.16$

$130,686.1 €$

*distance $10 \mathrm{~km}$, speed $50 \mathrm{~km} / \mathrm{h}$, time $0.2 \mathrm{~h}$, load $75 \%$, SFOC $157.5 \mathrm{~g} / \mathrm{kWh}$, engine power $200 \mathrm{~kW}$ 
The range of value of external costs on the alternative traffic routes varies from 7,663.31 $€$ per year in road traffic of passenger cars using gasoline to $359,916.48 €$ per year in maritime ferry traffic if MDO is used. Actually, they are at least 2.4 times higher on the targeted sea route than on the alternative road route. Fuel change from MDO to Euro diesel reduces external costs by $13 \%$ on this ferry line.

\section{DISCUSSION AND CONCLUSIONS}

The results of the research unambiguously point to road traffic as ecologically more acceptable on the investigated traffic route. This result is significantly affected by the absence of congestion and traffic accidents on this sparsely inhabited Adriatic island. This confirms the need to test the local traffic features on all traffic routes when calculating the external costs. Despite the benefit of the island's ferry connection and the existing port infrastructure in Komiža, the internalization of external costs wouldr represent a significant expense for the local community. This result is confirmed by the study (Martinez de Osez, 2008), pointing out that there are no savings in external costs on their investigated maritime lines in relation to road routes but that, nevertheless, there should be a continuation of public incentives to maritime traffic for better ecological performances in relation to road traffic. The increase in road traffic would certainly have had an impact on the conclusions of this research; however it is difficult to expect it due to a continuous decline in population. It is important to mention the use of Euro diesel fuel in ferries of the national liner (Jadrolinija, 2016), which has significantly reduced the external costs of the investigated maritime line but still not enough to be ecologically competitive to the road route. The research (Vukić et al., 2018) has already indicated the implementation of advanced emission reduction solutions to be the slowest in maritime traffic and currently there are no significant differences among road, rail, and maritime traffic as far as climate change external costs are concerned. This research points out the sensitivity of introducing external costs as a competitive factor on the traffic route. The perspective of the future research should be related to the possibility of introduction of alternative fuels that could change the current relations on the specific traffic route.

\section{REFERENCES}

Ančić, I., 2016., Energetska učinkovitost i ekološka prihvatljivost brodskih integriranih energetskih sustava. Doctoral Thesis. Univeristy of Zagreb.

Costal Liner Service Agency, 2018. Traffic of passengers and vehicles, Comparison of traffic in 2017 and 2016, Split, 2017. Available at: http://www.agencijazolpp.hr/ Portals/12/download/Promet_putnika_i_vozila_2017.pdf, accessed on: 15 October 2018.
Croatian Bureau of Statistics, 2011. Census of Population. Available at: https://www. dzs.hr/hrv/censuses/census2011/censuslogo.htm, accessed on: 09 January 2019.

European Commission, 2009. A sustainable future for transport - Towards an integrated, technology-led and user-friendly system. Luxembourg: Publications Office of the European Union, 26.

ICCT, 2016. The International Council on Clean Transportation, NOX emissions from heavy-duty and light-duty diesel vehicles in the EU: Comparison of realworld performance and current type-approval requirements. Available at: https://www.theicct.org/sites/default/files/publications/Euro-VI-versus-6_ICCT_ briefing_06012017.pdf, accessed on: 18 October 2018.

Jadrolinija, 2016. Izvještaj poslovanja za 2015.g., Rijeka, Hrvatska. Available at: https://www.jadrolinija.hr/docs/default-source/.../godišnji-izvještaj-za-2015. pdf?sfvrsn accessed on: 09 January 2018.

Jadrolinija, 2018. Ferry line - 602 Vis - Split. Available at: https://www.jadrolinija.hr/... plovidbe/602-vis-split, accessed on: 16 October 2018

Korzhenevych, A. et al., 2014. Update of the Handbook on External Costs of Transport, Final report for European Commission, RICARDO-AEA, Oxfordshire, UK.

M. Maibach et al., 2008. Handbook on estimation of external costs in the transport sector - IMPACT D1. INFRAS, Report Delft, CE Delft, Netherlands.

Martinez de Osez, F.X. \& Castells, M., 2008. Analysis of the external costs of selected short sea shipping vessels against the road alternative, UPCommons, Department de Ciència i Enginyeria Nàutiques, TRANSMAR - Grup de recerca de transport marítim i logística, Universitat Politecnica de Catalunya, Barcelona. Available at: http://hdl.handle.net/2117/2540, accessed on: 16 October 2018

Runko Luttenberger, L., 2012. Održivost male obalne plovidbe. IV. Savjetovanje o morskoj tehnologiji, Opatija, pp. 295-313.

Ship Spotting.com, 2018. Petar Hektorovic - IMO 8702446 - Callsign 9A6551. Available at: http://www.shipspotting.com/gallery/photo.php?lid=207710, accessed on: 16 October 2018.

Split and Dalmatia County Tourist Board, 2018. Statistical analysis of tourist traffic 2017. Available at: https://www.dalmatia.hr/.../statistike/statisticka-analizaturistickog-prometa-u-2017-godini, accessed on:16 October 2018.

Statistics Norway, 2017. Emission factors used in the estimations of emissions from combustion. Available at: https://www.ssb.no/_attachment/291696/ binary/95503?_version, accessed on: 16 October 2108.

TU Delft, 2012. The Model of the Eco-costs / Value Ratio (EVR), Eco-costs of emissions (Virtual Pollution Prevention Costs, VPPC). Delft University of Technology, Netherlands. Available at: http://www.ecocostsvalue.com/EVR/model/theory/2emissions.html, accessed on: 09 January 2019.

Van Lier, T., 2016. An external cost calculator framework for evaluating the sustainability of ., transport solutions. HEC Management School - University of Liège, Brussel: Vrije Universiteit.

Vukić, L. \& Poletan Jugović, T., 2016. Planning and valorization of the branch Xa of Corridor X from the aspects of external costs. Pomorstvo, 30(2), pp.151-159. Available at: http://dx.doi.org/10.31217/p.30.2.8.

Vukić, L., Ukić Boljat, H., Slišković, M., 2018. Comparison of climate change cost of freight road, rail and maritime transport. Conference Proceedings Maritime, Transport and Logistics Science, Portorož, Slovenia, pp.405-408. 